\title{
PRINCIPLES OF MODERN PROFESSION TRAINING THE FUTURE SPECIALISTS FOR RAILWAY TRANSPORT IN “COLLEGE- UNIVERSITY" SYSTEM
}

\author{
Nataliia Malanyuk ${ }^{1}$ \\ ${ }^{1}$ PhD (Pedagogical Science), Lecturer of the Cycle Commission of General Education Disciplines \\ (Mathematics, Higher Mathematics), Kyiv College of Transport Infrastructure, Kyiv, Ukraine, e-mail: \\ malanyuk.nat@gmail.com, ORCID: https://orcid.org/0000-0002-4321-0900
}

\begin{abstract}
The events in the modern world is characterized by global and overall processes which penetrate every branch of society. Transforming processes of euro integration need the new requirements for future specialists - graduating students of higher and pre-higher professional educational institutions. As transport infrastructure takes one of the main places in economical system of every country, so the important questions of nowadays are the training of future specialists for railway transport and the search for ways of improvements the quality of such kind of training. The task of modern educational institutions is to respond quickly to the changes in the world tendencies (economic, educational, scientific, informational, technical, social). The aim of the article: research, separation and reasoning the number of principles taking into account of which, in our point of view, favour the improvement the quality of training the future specialists for railway transport. Research methodology: using the general theoretic method of scientific research and methods of analysis and synthesis as well. Results received: in course of our research there were such important principles the implementation of which help increase the efficiency of professional training the future specialists for railway transport in the system of continuous gradual education: the principle of three components unity science - theory - practice; the principle of key role of activity; the principle of humanism (humanization); the principle of knowledge integrity; the principle of democratization; principle of creation «knowledge values» system; the principle of dynamism in education, knowledge mobility; the principle the unity of studies and upbringing formation world-view, values, moral, standards of behavior etc.); the principle of the system and consistency (a transition between the levels of vocational education); the principle of continuity of education (life-long learning); the principle of forming the motivational system of activity (professional); the principle of knowledge informatization; the principle of important role of a teacher; the principle "education for future". Practical value: in the researches we took into account the principles, which became basial for the creation the pedagogical system in course vocational education of future specialists for railway transport and favour the improvement the quality of educational process in higher (professional pre-higher) education.
\end{abstract}

Keywords: professional education, principles, future specialists, "college - university" system, professional training.

JEL Classification: I0; I20

Formulas: 0; fig.: 0; tabl.: 0; bibl.: 14

Introduction. The second decade of the XXI century is marked by global and overall processes which penetrate every branch of society. Transforming processes of European integration need the new requirements for future specialists - graduating students of higher and pre-higher professional educational institutions. As transport infrastructure takes one of the main places in economical system of every country, so the important questions of nowadays are the training of future specialists for railway transport and the search for ways of improvements the quality of such kind of training.

Modern education is in the state of active search of means, methods, ways for achievement of certain harmony between public demands and needs of every 
personality. Pedagogical theory and practice of nowadays are full of various approaches and ideas (based on psychology, philosophical conceptions etc.). The researcher I. Bekh (2005) emphasizes that educational space is intensively filled with the «imperative of humanism and democratization» each time [1, p.7]. A student becomes the center of educational process, and the content of vocational education is forming of personality, future professional with the development of qualities, necessary for gaining professional competence, creation the vision of life entirety, where the education is the central component, a person's demand. An educator, who teaches the certain subject, has to personify not only the best qualities of a person knowing the subject and the teaching methodology, but also be well-informed about the approaches of personality's modeling and development as the subject of educational activity, and also willingness and capacity to use own knowledge and abilities in everyday activity.

Literature Review. The works of such researchers as Bereza V. [2], I. Bekh [1], N. Nychkalo (2008) [4], M. Romanenko [5], V. Syvologa [7] are devoted to the problems of vocational education, its modernization and introduction of innovative approaches, receptions and technologies. Conceptual principles of continuous vocational education and the separate aspects are analysed in research works of these authors. However, the question of professional training of future specialists for railway transport in «college-university» system, the improvements of quality of such preparation remains not revealed enough.

Principle (from lat. principium is basis, beginning). Principles of studying in higher educational institutions are base positions, and the choice of content, methods, forms and means of teaching are based on them. The principles are subordinated to the objective of study.

Researchers consider such principles of vocational education: surpassed character of professional preparation; fundamentalisation; integration of vocational education, science and production; equal access for all levels of population to acquisition of high-quality vocational education; flexibility and correlation of process vocational education with restructuring and the further development of economics and population's employment, the development of different forms of property; diversification; vocational education in different regions; unity of general education and vocational training; standardization; unity of vocational training and education; professional education; ecologization; variability, personification and differentiation [4, p.87-88].

The scientist V. Sivologa (2013) in the concept of "humanization of education" distinguishes such components:

- process with characteristic features;

- orientation of development the education on humane relationships in society as universal value;

- stablishing the personality as the greatest value;

- providing the priority of interests of those who study;

- humanization of all content of educational activity; 
- targeting the education on development the personality, forming mechanisms of self-education and self-training, for realization of person's creative potential [7, p.273-274].

At the same time, researcher M. Romanenko recognizes such peculiarities of modern higher education which, partly or fully, do not let implement in life the ideas of humanistic education:

- considering education as personnel - professional point of view (preparation of specialists and professionals, but not personality, in educational institutions);

-knowledge is the priority of education (although knowledge is greatly changeable);

- system of standards of educational process success eliminates the needs of personality;

- evaluation of knowledge (competences, skills), but not their influence on personality development;

- low level of person's activity in educational process;

- determination of forms, ways, methods and content of studying by pedagogical staff without a person who gets education [5].

However, vocational education is also affected by the influence of European integration processes, the mobility of labor market and the growing demands on the quality of training of future railway transport specialists, and such education has to react as it is an integral part of human being. If vocational education doesn't change to respond modern requirements of society, it will change into formal "passing the information".

Rapid scientific and technological progress, the penetration of information technology in every field of human activity, large arrays of information, which is getting old and updated rapidly, should change the professional training of future railway transport specialists, as well, as the key tasks of vocational education are urgency, purposefulness, ability to think, analyze, gain professional competencies (competencies), the need and desire for self-development, self-improvement, etc.

The scientists of the XXI century call society a "knowledge society". The author of this term is P. Drucker (1995), who believed that knowledge alone can not produce anything until it is used to solve a specific problem, in turn, the tasks are dictated by society, which the scientist called "knowledge society" [3]. The author spoke at the UNESCO Assembly (2005), the key theses of the speech were as follows:

- the knowledge society has broader parameters than the information society (social, economic, ethical, etc.);

- means of knowledge distribution are education, radio, television, press, Internet, multimedia;

- special attention to textbooks and teachers;

- the informative aspect of education is important for the knowledge society;

- the existence of not only "electronic information gap", but also "cognitive gap" [8].

Researcher M. Weber (1980) emphasizes that the definition of "knowledge society" is to some extend technical, a kind of ideal construction [9]. 
Psychologist V. Shadrykov (1982) points out that the first stage associated with professional activity is the adoption of profession; the next is the desire to perform it in a certain way [6, p.37]. The latter, according to the author, serves as the starting point for the formation of psychological system of activity.

Aims. The purpose of the article is to investigate, identify and reasoning a number of principles, taking into account which, in our opinion, will help improve the quality of training of future specialists in railway transport.

Methods. Achieving the goal of the research made it possible to use the general theoretical method of scientific research, as well as methods of analysis and synthesis.

Results. The task of modern institutions of higher education is to respond effectively to changes in world tendencies (economic, educational, scientific, informational, technical, social). In the course of our study, the following principles were important and the implementation of which helps to increase the efficiency of professional training of future railway transport specialists in the system of continuous education:

- the principle of three components unity of science-theory-practice;

- the principle of the key role of activity (scientist I. Bekh called the activity principle - "genesis principle": maximum cognitive activity during the process of cognitive activity [1, p.7].);

- the principle of humanism (humanization);

- the principle of knowledge integrity;

- the principle of democratization;

- the principle of creation "knowledge values" system;

- the principle of dynamism in education, knowledge mobility;

- the principle of unity of education and upbringing (formation of worldview, values, morals, standards of behavior, etc.);

- the principle of system and consistency (transition between levels of vocational education);

- the principle of continuity of education (lifelong learning);

- the principle of forming the motivational system of activity (professional);

- the principle of knowledge informatization;

- the principle of the important role of the teacher;

- the principle of "education for the future".

In our research, we took into account the principles that have become fundamental in creation a pedagogical system of vocational education for future railway professionals. Examine the characteristics of these principles.

Discussion. The principle of unity of the three components "science-theorypractice". The effectiveness of the higher education system lies in its profoundness, which is based on scientifically reasonable theories. The important standard of higher professional education (professional pre-higher education) should be, on the one hand, the scientific and educational processes unity, and on the other - the theory and practice unity. Students need to be taught to analyse, think, query information. It is 
the development of these functions of thinking will help future professionals to develop, improve, implement innovations and think creatively.

The principle of the key role of activity. Activity (educational, cognitive, future professional) occupies a leading place in educational process. The formation and development of such qualities, competencies, functional processes that should be intrinsic to the future professional are developed exactly in activity and through activity. The educational institution (teacher) acts as an organizer of such activities, ensuring the formation of creative educational environment.

The principle of humanism. The Laws of Ukraine "On Education", "On Higher Education", "On Professional Pre-Higher Education" point out that the purpose of education is "comprehensive development of the individual as the highest social value".

In order to implement this principle in higher (professional higher) educational institutions, it is necessary to pay special attention to the formation and development of each individual as a subject of the educational process; knowledge should not be considered "absolute", but to form the ability to learn (search for new knowledge); take into account the needs of each participant in the educational process; increase the students' cognitive activity in the educational process, etc.

The principle of knowledge integrity. It involves the formation holistic scientific worldview, the use of knowledge not as purely presentive, but as "meta-subject", which are integrated, systematized, generalized, inter-complemented in single scientific picture. This can be achieved by examining each object through the prism of different sciences (characterization of hierarchical and causal relationships between objects, objects and phenomena, between phenomena, etc.).

The principle of creation "knowledge values" system. Knowledge is not a kind of "absolute", the eventual result of the educational process, but is only the way, the way to acquiring other knowledge. Knowledge is the basis for skills and abilities, as well as competencies.

The principle of dynamism in education, knowledge mobility. The XXI century is characterized by rapid globalization processes in the economy, politics, world society. The reason was the rapid development of science and technology, mobility of information (speed of information dissemination, its transmission). Education as a social (state) institution must also be developing together with society. Otherwise, it will decline, as it will be unable to meet the demands of society, which is increasing exponentially. Higher education institutions need to change in their own concepts and statutes, and on the basis of the latter changes, in their activities.

Knowledge is necessary for the formation of holistic scientific picture of the world, its key feature is mobility, namely, the ability to move from one branch of science to another, the usage of integrated approaches, the integration of knowledge.

The principle of unity of teaching and upbringing. Regardless of the orientation of the educational institution, in our opinion, it is important to educate future professionals in the following areas: patriotic education (love for the Motherland, its people); moral education (the concept of good and evil, respect to another person, etc.); ecological education (careful attitude to nature and everything that surrounds a 
man, the search for technologies that can minimize the negative impact on the environment); aesthetic education (sense of beauty, harmony); physical education (healthy lifestyle, value of health).

The principle of continuity of education. Education of the XXI century is characterized by its dynamism: the variability of information, means of labour, forms and methods of professional activity. Life follows the socio-economic progress, as well as scientific and technological. All this makes demands for each personality: constant improvement, constant learning. Continuity of education (including professional) is a requirement of nowadays.

The principle of forming he motivational system of activity. During the studies in educational institutions, teachers, administration, etc. need to help students form a clear system of values and positive motivation for both educational activities and future professional.

The principle of informatization the education. Information is the basic category that a person contacts at all times. In recent decades, there has been accumulated so much information that it has become impossible (not even necessary) to keep it all "in your head".

The task of the higher education "college-university" system is to teach future professionals to search, evaluate, analyze, summarize, store and transmit information: among the proposed extremely large amount of information to choose the necessary (reliable) one that will be transformed into knowledge (skills, competence) etc). Also, this principle includes the informatization (computerization) of professional activities: work with special equipment, as well as with special software.

The principle of important role of the teacher. The teacher in higher educational institution performs a number of basic functions (in relation to students): organizational and corrective, sources of scientific and educational information, monitoring and control. In relation to themselves, the teachers must constantly improve their professional level: to be interested in innovations within their discipline, as well as general pedagogical and methodological innovations; to increase the level of professional culture (carrying out scientific activities, communicating with students and colleagues, etc.).

The college teacher forms the idea of the future profession, the requirements for profession performing, helps to form values and motivational guidelines for mastering the profession in each student, as well as further improvement (training). The moral qualities of the teacher, his life position also favours the formation of a future specialist - a citizen of Motherland, who respects himself and others and so on.

The principle of "education for the future". In recent decades, there has been a significant gap in our country vocational education between the knowledge (skills, abilities, etc.) that students received by studying in higher educational institutions (college, university) and the demands (requirements) of employers to their potential employees. The level of development of modern education generally does not correspond to the level of development of those industries in which future professionals must work. The key goal of higher educational institution should be to train professionals "of the future" (and to the future) who will meet the challenges of 
today, who have the appropriate competencies to improve and change in accordance with the requirements of professional activity (space-time). Education today cannot be the kind it was yesterday. A person changes every day and all spheres of his life, society changes with him at the same time. Therefore, education, as a social link, must also evolve with society: the knowledge society, the information society, and so on.

Conclusion. The professional training of future specialists for railway transport must correspond to the modern state of development of education, science, technology, as well as general world tendencies in the industry, the requirements for specialists and the quality of their work. Therefore, it is important to review educational professional standards regularly, as well as to take into account when creating the system of vocational education principles that are based on demands and needs of society and each individual. In course of our research there were such important principles the implementation of which help increase the efficiency of professional training the future specialists for railway transport in the system of continuous gradual education: the principle of three components unity science theory - practice; the principle of key role of activity; the principle of humanism (humanization); the principle of knowledge integrity; the principle of democratization; principle of creation «knowledge values» system; the principle of dynamism in education, knowledge mobility; the principle the unity of studies and upbringing formation world-view, values, moral, standards of behavior etc.); the principle of the system and consistency (a transition between the levels of vocational education); the principle of continuity of education (life-long learning); the principle of forming the motivational system of activity (professional); the principle of knowledge informatization; the principle of important role of a teacher; the principle "education for future". The principles highlighted in our study were taken into account while creating the model of the system for professional training of future railway transport specialists according to conditions of continuity of professional education. Our further research will be aimed at implementing this model to system of professional training of future railway transport specialists in the practical activities of higher and professional higher educational institutions.

\section{References:}

1. Bekh, I. (2005) Pryntsypy innovatsiinoi osvity [Principles of innovative education] Education and management. Volume 8. №3-4. 2005. P.7-20 [in Ukrainian]

2. Bereza, V. (2015) Demokratyzatsiia suspilnykh vidnosyn yak holovna umova funktsionuvannia politychnoi osvity y prosvitnytstva [Democratization of public relations as the main condition for the functioning of political education and enlightenment] Bulletin of the Institute of Child Development. Series: Philosophy, pedagogy, psychology. Issue 37. p.10-17. [in Ukrainian]

3. Drucker, Peter F. The End of Economic Man: The Origins of Totalitarianism. 1995. 167 p. [in English]

4. Nychkalo, N. G. (2008) Transformatsiia profesiino-tekhnichnoi osvity Ukrainy: monohrafiia. [Transformation of vocational education of Ukraine: monograph] K.: Pedahohichna dumka. 200 p. [in Ukrainian]

5. Romanenko, M. I. (2001) Humanizatsiia osvity: kontseptualni problemy ta praktychnyi dosvid: naukova monohrafiia [Humanization of education: conceptual problems and practical experience: scientific monograph]. Dnipropetrovsk: Promin. [in Ukrainian]

6. Shadrikov, V. D. (1982) Problemy sistemogeneza professional'noj dejatel'nosti. [Problems of systemogenesis of professional activity]. M .: Nauka.186 p. [in Russian] 
7. Syvologa, V.F. (2013) Гуманізація та гуманітаризація вищої освіти. [Humanization and humanitarianization of higher education]. Research of political interaction in the conditions of society transformation: collection. Science. Odessa: ONU. P.266-286. [in Ukrainian]

8. To Knowledge Societies: UNESCO World Report (2005). Paris: UNESCO Publishing House.240 p. [in English]

9. Weber M. Social Action Theory. Electron reassures. Retrieved from: https://revisesociology.com [in English]

Received: November 18, 2020 Approved: December 11, 2020 